\title{
The representations of adolescents about gynecological consultation
}

\author{
REPRESENTAÇÕES DE ADOLESCENTES ACERCA DA CONSULTA GINECOLÓGICA \\ REPRESENTACIONES DE ADOLESCENTES SOBRE LA CONSULTA GINECOLÓGICA
}

\begin{abstract}
Vera Lúcia de Oliveira Gomes ${ }^{1}$, Adriana Dora da Fonseca ${ }^{2}$, Denize Cristina de Oliveira ${ }^{3}$, Camila Daiane Silva ${ }^{4}$, Daniele Ferreira Acosta ${ }^{5}$, Fabiani Weiss Pereira ${ }^{6}$
\end{abstract}

\begin{abstract}
Objective: To analyze the social representation of adolescents about gynecological consultation and the influence of those in searching for consultations. Method: Qualitative descriptive study based on the Social Representations Theory, conducted with 50 adolescents in their last year of middle school. The data was collected between April and May of 2010 by Evocations and a Focal Group. The software EVOC and contextual analysis were used in the data treatment. Results: The elements fear and constraint, constant in the central nucleus, can justify the low frequency of adolescents in consultations. The term embarrassment in the peripheral system reinforce current sociocultural norms, while prevention, associated with learning about sex and clarifying doubts, allows to envision an educative function. Obtained testimonies in the focal groups exemplify and reinforce those findings. Conclusion: For an effective health education, professionals, including nurses, need to clarify the youth individually and collectively about their rights to privacy, secrecy, in addition to focus the gynecological consultation as a promotion measure to sexual and reproductive health.
\end{abstract}

\section{DESCRIPTORS}

Adolescent

Sex education

Sexual health

Reproductive health

Free association

Nursing

\section{RESUMO}

Objetivo: Analisar as representações sociais de adolescentes acerca da consulta ginecológica e a influência dessas representações na procura pela consulta. Método: Estudo qualitativo descritivo fundamentado na Teoria das Representações Sociais, realizado com 50 adolescentes que cursavam o último ano do ensino fundamental. Os dados foram colhidos entre abril e maio de 2010 por meio de Evocações e Grupo Focal. Utilizou-se o software EVOC e análise contextual no tratamento dos mesmos. Resultados: Os elementos medo e constrangedor, constantes no núcleo central, podem justificar a baixa frequência de adolescentes nas consultas. No sistema periférico o termo vergonha reforça normas socioculturais vigentes, enquanto prevenção, associado a aprender sobre sexo e esclarecer dúvidas, permitem vislumbrar uma função educativa. Depoimentos obtidos nos grupos focais exemplificam e reforçam esses achados. Conclusão: Para uma educação em saúde efetiva, os profissionais, especialmente enfermeiros, precisam esclarecer os jovens, em nível individual e coletivo, sobre seus direitos à privacidade, sigilo, além de enfocar a consulta ginecológica como medida promotora da saúde sexual e reprodutiva.

\author{
DESCRITORES \\ Adolescente \\ Educação sexual \\ Saúde sexual \\ Saúde reprodutiva \\ Associação livre \\ Enfermagem
}

\section{RESUMEN}

Objetivo: Analizar las representaciones sociales de adolescentes acerca de la consulta ginecológica y la influencia de estas representaciones en la demanda por la consulta mencionada. Método: Estudio cualitativo, descriptivo basado en la Teoría de las Representaciones Sociales, realizado con 50 adolescentes que cursaban el último año de la escuela primaria. Los datos fueron recolectados entre abril y mayo del 2010 por medio de Evocaciones y Grupo Focal. Se utilizó el software EVOC y el análisis contextual en el tratamiento de los datos. Resultados: Los elementos miedo y vergüenza, constantes en el núcleo central, pueden explicar la baja frecuencia de adolescentes en las consultas. En el sistema periférico el término vergüenza refuerza normas socio-culturales vigentes, mientras que, prevención, asociado al aprendizaje sobre sexo y aclaración de dudas, nos permiten vislumbrar una función educativa. Declaraciones obtenidas en los grupos focales ejemplifican y refuerzan estos hallazgos. Conclusión: Para una educación en la salud eficaz, los profesionales, especialmente enfermeros, necesitan aclarar a los jóvenes, en el nivel individual y colectivo, sobre sus derechos a la intimidad y la confidencialidad, además de enfocar la consulta ginecológica como una medida de promoción de la salud sexual y reproductiva.

\section{DESCRIPTORES \\ Adolescente \\ Educación sexual \\ Salud sexual \\ Salud reproductiva \\ Asociación libre \\ Enfermería}

\footnotetext{
${ }^{1}$ Full Professor, Nursing School, Universidade Federal do Rio Grande, Rio Grande, RS, Brazil. vlogomes@terra.com.br ${ }^{2}$ Associate Professor, Nursing School, Universidade Federal do Rio Grande, Rio Grande, RS, Brazil. ${ }^{3}$ Full Professor, Nursing Graduate Program, Universidade do Estado do Rio de Janeiro, Rio de Janeiro, RJ, Brazil. ${ }^{4}$ Master's Student at the Nursing Graduate Program, Universidade Federal do Rio Grande, Rio Grande, RS, Brazil. ${ }^{5}$ Doctoral Student at the Nursing Graduate Program, Universidade Federal do Rio Grande, Rio Grande, RS, Brazil. ${ }^{6}$ Master's Student at the Nursing Graduate Program,
} Universidade Federal do Rio Grande, Rio Grande RS, Brazil. 


\section{INTRODUCTION}

During adolescence, sexuality is manifested as new and surprising needs and body sensations, unknown desires and in the search for a interpersonal relationship ${ }^{(1-2)}$. Between many transitions that happen during this phase of life, the passage of sexuality with a partner is the one of most repercussion ${ }^{(1)}$. Its learning is not restricted to genitality nor to the first sexual relationship, but it results from individual experiences and influences, legitimated by the group culture ${ }^{(3)}$. Thus, the desire to fully experience sexuality and to experiment the new, associated with peer pressure and curiosity, common in this phase, constitutes situations that can at least partially explain the adolescence vulnerability.

Research regarding sexual experience in adolescents in India, Latin America and South Africa reveal elevated vulnerability in this age group ${ }^{(4-6)}$. The main indicated factors were early sexual initiation and need to adopt measures to help adolescents adopting safe sexual practices ${ }^{(5)}$; insufficient information about sexual and reproductive health in advising services, having as consequence, a low number of adolescents sexually active being preventive against Sexually Transmitted Disease (STD) ${ }^{(4)}$. Showing another problem dimension, studies point that although adolescents have knowledge about preservatives they still adopt a risky sexual behavior ${ }^{(6-7)}$.

In Brazil, epidemiologic data gave dimension to this problem when revealed that approximately $17 \%$ of teenagers had their first sexual relationship before 14 years old in 2007 . At this same year, about $26 \%$ revealed having more than 10 partners in life ${ }^{(8)}$. Data also showed that use of preservatives with casual partners decreased from $58 \%$ approximately in 2004 to $49 \%$ in $2008^{(8)}$.

STDs and early pregnancy are among the consequences most associated with those behaviors ${ }^{(9)}$. Although the Health Ministry had announced the expressive reduction of $22.4 \%$ in the number of adolescent births in the public health system between 2005 and 2009(10), health promotion actions should be sustained. Regarding the STDs, 66.698 cases of Aids were diagnosed between youngers of 15 to 24 years old, from 1982 to $2011^{(8)}$. Thus, the epidemiologic characteristics from the adolescence population in addition to worried educators, parents, governors and researchers, points to an imperious intensification of sexual and reproductive health promotion actions, between those, the adoption of a gynecological consultation routine.

It is a space aimed to propose gynecological assistance to adolescents through prevention actions and health maintenance ${ }^{(11)}$. Professionals need to invest in the interpersonal relationship contemplating the ethic precepts, the social norms and the adolescent's specificities ${ }^{(11)}$. In the gynecological consultation, it is possible to develop an educational process that surpasses the information transmission about the biological aspects, that include the adolescent's self-esteem promotion, that help them to see themselves as protagonists of their lives and, therefore, responsible for their actions and conscientious of risks which they are exposed to ${ }^{(12)}$.

However, little are those who take advantage of this moment in the health service because there are obstacles; as the difficulty to schedule an appointment, the impossibility to choose a professional, attendance that do not contemplate their specificities, fear of secret disclosure added to misinformation ${ }^{(11)}$. It is known that adolescents tend not to share their reproductive decisions with those responsible for them ${ }^{(11)}$ and the consultation is a resource to clarify doubts with professionals.

In the gynecological consultation, it is possible to communicate about the adoption of behaviors that incite a healthy and pleasurable sexual experience. Besides that, it gives the opportunity to put in context themes related to non-desired pregnancy prevention and STD/HIV/Aids. Thus, the need of a pedagogic approach involving information, associated to a reflexive analysis and the adolescent's feelings ${ }^{(8)}$ is highlighted; to facilitate the adherence of this age group to routine consultation.

Considering the gynecological consultation as being an important sexual and reproductive health promotion action for adolescents, that it freely available in the basic health system and still, the search for it is low; the present study was developed to investigate the social representations of adolescents from the last year of middle school, about gynecological consultation. Therefore, the objective is to analyze the social representations of gynecological consultation for this population, and the influence of those in the search for a consultation.

\section{METHOD}

This is a qualitative descriptive study based on the Theory of Social Representations, conducted by the Structural Approach or Theory of Central Nucleus, which consist of a propose complementary to the theory. This approach allows to organize the representations revealing the relationships of the group maintained with the object in its subjective and objective dimensions ${ }^{(13)}$.

The study was conducted with 50 adolescents from the last year of middle school. Three schools from the city of Rio Grande/RS were part of the study. The school directors agreed to participate and helped doing the intermediate contact between the ones legally responsible for the adolescents and the researcher. The data was collected in a Municipal Public School, located on the outskirts of the city (EPP) and two in the central area, being a State Public School (EPE) and a Private School (EP).

The data collection was during the period of April $12^{\text {th }}$ and May $10^{\text {th }}$ of 2010 , it was done with the Free 
Evocations and Focal Group (FG) techniques. The first one allows apprehending the cognitions in a relaxed and spontaneous way, besides the opportunities to obtain the meanings by a rapid and objective chain, facilitating the evocation of the discursive expressions ${ }^{(14)}$. The FG allows the production of data and insights that would be less accessible outside the interactive context by group interviews ${ }^{(15)}$. It constitutes an important technique to the knowledge of representations, perceptions, beliefs, habits, prejudice and symbolisms surrounding a phenomenon, by people who share common and relevant traces ${ }^{(16)}$. The use of data triangulation appears to be relevant in research about social representation because it allows amplified knowledge surrounding the phenomenon from the perception of reality that is not only concrete, but also imaginary.

From the methodological point of view of the Free Evocations, the participants were asked to write the first five words that came to their heads immediately from the inductive term gynecological consultation. Regarding the FGs, two meetings in each school were done, one with girls and one with boys. All students from the last year of middle school were invited. The FGs were integrated by those interested who brought the Free Informed Consent signed by their legal responsible. Those groups had a master's student as a mediator and a scientific initiation fellow student as an observer; both from the Nursing School at the Universidade Federal do Rio Grande. The groups were developed in large rooms away from busy areas to allow more engagement and concentration. The mean duration of each meeting was 80 minutes.

In the girls' group, the provided questions were: If I told each of you that you have to do a gynecological consultation now, what would you feel? Which questions do you think would be done? Which exams would be asked and which ones would be done during the consultation? In the boys' group, the directed questions were: If your girlfriend asked you to accompany them to a gynecological consultation, what would you do? Which questions do you think it would be done to them? Why women should do this kind of consultation?

At the end of data collection, a workshop was developed in each school where they debated doubts and prejudices regarding the Gynecological Consultation, besides questions regarding the sexual and reproductive health.

The treatment of the evocations was done with the software EVOC 2003, allowing a chart construction with four houses, proposed by Pierre Vergès ${ }^{(14)}$, constituted by a Central Nucleus (CN), located in the superior left quadrant; contrast elements, located in the bottom left quadrant; and peripheral elements, located in the two right quadrants in the chart.

Elements are situated in the $\mathrm{CN}$ which gives meaning to the representation ${ }^{(13)}$. These elements are associated with the collective memory and the group's history. This way, the $\mathrm{CN}$ is somewhat sensitive to the immediate context and it is formed by the evoked terms with more frequency and readiness. The peripheral system is more flexible than the $\mathrm{CN}$, because it allows the integration of experiences and individual histories, giving space to contradictions and manifestation of the group heterogeneity ${ }^{(14)}$. Thus, the peripheral system is sensitive to the immediate context. The contrast zone is composed by words less evoked, but in the first positions and it has elements that express variations from the representation arisen from subgroups ${ }^{(14)}$.

The content analysis was conducted for the data treatment, collected by the FG, adopting the context unit for codification. It is a broader unit containing the register unit and allows the comprehension of its meaning ${ }^{(17)}$. For the interlocution between the two techniques, sentences with a register unit were selected from the data collected in the focal group sessions, that is, the words composing the central nucleus or those integrating the peripheral elements from the four houses chart, built from the evoked terms in this study.

To preserve anonymity, the boys' speeches were identified with the letter $\mathrm{R}$ and the girls' with the letter $M$, added with the number 1,2 or 3 to identify the schools EPP, EPE and EP, respectively; and the number correspondent to their names' alphabetical order. The project was approved by the Ethics in Research Committee in Health Sciences from the FURG under the protocol no 81/2009.

\section{RESULTS}

The 50 adolescents were between 14 and 17 years old. Among them, three boys and fifteen girls studied at EPP; five boys and eight girls at EPE and eleven boys and eight girls at EP. The words evoked by those participants from the inductive term Gynecological Consultation, allowed the construction of a four houses chart (Figure 1).

By the frequency and position in the rang, the terms fear, constraint and sex, located at the superior left quadrant, possibly compose the $\mathrm{CN}$, constituting more stable representation elements. The term fear was evoked 18 times, being situated 13 times in the first position; it is important to highlight that 11 informants evoked only this word. The term constraint and sex were evoked eight times each, being the last one always in first position.

From the obtained data of the focal group, sections were selected containing the cited terms during the free evocations technique and they compose the chart with four houses. This content manifested during the group interaction allow to rescue the context in which they use in their everyday. Thus, the terms fear, constraint and sex were used to describe the reasons why they do not go to the gynecological consultation.
The representations of adolescents about gynecological consultation Gomes VLO, Fonseca AD, Oliveira DC, Silva $C D$, Acosta DF, Pereira FW 


\begin{tabular}{|c|c|c|c|c|c|}
\hline \multicolumn{3}{|c|}{ Frequency $>=5.3 /$ Rang $<=1.67$} & \multicolumn{3}{|c|}{ Frequency $>=5.3 /$ Rang $>=1.67$} \\
\hline & FREQ & RANG & \multirow{4}{*}{$\begin{array}{l}\text { Prevention } \\
\text { Embarrassment }\end{array}$} & FREQ & RANG \\
\hline Constraint & 8 & 1,500 & & 5 & 1,800 \\
\hline Fear & 18 & 1,389 & & \multirow[t]{2}{*}{9} & \multirow[t]{2}{*}{2,111} \\
\hline Sex & 8 & 1,000 & & & \\
\hline \multicolumn{3}{|c|}{ Frequency $<5.3$ / Rang $<1.67$} & \multicolumn{3}{|c|}{ Frequency $<5.3 /$ Rang $>=1.67$} \\
\hline & FREQ & RANG & & FREQ & RANG \\
\hline Women & 2 & 1,000 & Learn about sex & 4 & 2,500 \\
\hline Doctor & 4 & 1,500 & Boring & 4 & 2,750 \\
\hline Nervousness & 2 & 1,500 & Pain & 2 & 2,500 \\
\hline \multirow[t]{2}{*}{ Vagina } & 3 & 1,000 & Clarify doubts & 3 & 2,667 \\
\hline & & & Pregnancy & 2 & 2,000 \\
\hline
\end{tabular}

Figure 1 - Chart with four houses for the inductive term GYNECOLOGICAL CONSULTATION of a group of students from the last year of middle school - Rio Grande, 2010.

by fear and constraint, lack of information about what happens in the consultation, by having many doubts of how it is the consultation....and...because the mother have to go together. We don't want her to know things... of everything is impossible, right? (M.1.6).

by fear, constraint and embarrassment, because it is something new, because you need to take the clothes off and show those parts (M.2.2)

my mother said is kind of bad; you have to take your clothes off. Imagine! To be naked in front of a man that l've never seen...I don't take my clothes off in front of my mom (M.3.8).

Discoursing about the possible questions made in a gynecological consultation, the adolescents mentioned questions pointed to the term sex that is in the $\mathrm{CN}$, referring to sexual intercourse.

the age, if we are virgins, what age was our first time, a lot of questions that make us constrained. It is hard to talk about it (M.1.3).

In the superior right quadrant are the most important peripheral elements, constituting the first periphery, being prevention and embarrassment. The last one was evoked nine times, being three times in first position. When questioned about the reasons for not doing a gynecological consultation:

ah this one is easy...because we are embarrassed...we get nervous....and if you don't have sexual relationship I think you don't have to go... (M.1.5).

no, but I'm not going to feel embarrassed outside the clinic, I'm going to feel embarrassed when I get in and take my clothes off, the doctor will touch me, and to put that thing... (M.2.4). embarrassment, fear, and many of them also don't know they have to go when they are not virgins anymore and they don't want the parents to know they are not virgins... (M.3.3).

The term prevention presents a degree of importance relatively lower and, by the speech analysis, seems to refer to pregnancy and Sexually Transmitted Diseases:

when you start dating at home the mother is the first to say, if you are going to give anything you have to go to the doctor at first... (M.3.2).

to obtain information about sex, sexuality, diseases and pills (M.2.2).

In the inferior right quadrant there are elements of second periphery in this study, composed by the terms learn about sex, boring, pain, clarify doubts, and pregnan$c y$. In this quadrant the terms learn about sex and boring were the elements more evoked, both four times. Those terms emerged when adolescents talked about the reasons to go to the gynecologist:

to solve doubts...for clarifications about the body... (M.1.3).

to know if there is any problem, if everything is normal... if is everything is fine, right? to know more about sex, to know more...to know how to prevent myself...(M.3.1).

The desire of getting involved in questions related to the women sexual and reproductive health was present in the discussion among boys. Imagining to be invited to accompany their girlfriends to a gynecological consultation, three responded affirmatively:

absolutely, to learn more about the female gender, and I would be happy, I would think that she wants me to partici- 
pate more in her life and to know more about her situation, even to help somehow (R.3.4).

On the other side, one was surprised and other 15 boys were reluctant to the possibility, reproducing the representation that this is an attribution for women.

it is an unexpected question, I wouldn't expect her to ask me that...because it is not in a boy's mind that your girlfriend would ask you that! (R.1.2).

this is a mother task! I wouldn't go, I think, in this case, it is better for the girl to go with her mom than with me... (R.3.5).

In the bottom left quadrant, there are elements of the contrast zone that in this analysis were woman, nervousness, vagina and doctor. Those elements center the gynecological consultation in the female reproductive tract, confirmed by the higher number of evokes to the term doctor, four times, and vagina, three times. Besides that, some speeches show the lack of information about the purposes of the referred consultation.

it is the PAP test, the digital examination, but uses that thing, you know? That looks like a duck beak (M.1.2).

but this only happens when the women is not virgin anymore, and after a year, seems like... before that you cannot do it (M.2.8).

if there is no sexual relationship, it is not needed...when you start to have sexual relationship is when you have to go, to take pills and to check if everything is all right (M.2.4).

\section{DISCUSSION}

The CN performs the structural and functional functions of a social representation, having as most significant ownership, the guarantee of stability ${ }^{(14)}$. The structural or normative function is performed in situations when norms, stereotypes or rooted attitudes are in the center of representation ${ }^{(14)}$. Thus, the presence of the terms fear and constraint in the $\mathrm{CN}$ of Gynecological Consultation representation can find the interference of socio-affective or ideological dimensions ${ }^{(14)}$, making us believe that sociocultural norms, strongly marked, are in the center of this social representation.

Those norms seem to be consensual among parents, educators and health professionals who use the most diverse practices to keep them. Accordingly, although it is a public domain that sexual initiation among adolescents is happening increasingly early ${ }^{(5,8)}$, there is an enormous difficulty to accept as natural the sexual activity in this age group ${ }^{(18)}$. Trying to avoid or stop the sexual initiation of a teenager daughter, many families threat, reproach and criticize constantly. Health professionals also adopt an incoherent conduct, as they frequently approach related themes to sexual and reproductive health promotion for adolescents in school, but when those adolescents seek for them in the Health Services, to obtain inputs for STD and pregnancy prevention, they are told that they will provide it only if accompanied of those responsible for them. It demonstrates that for the health professionals it is also difficult to accept the sexual activity between adolescents ${ }^{(8)}$.

Those postures do not minimize curiosity, neither discourage sexual practices, it only induces adolescents to keep their sexual life in secrecy and consequently, to assume the related risks. In addition, it ends with any possibility of dialogue related to sex, because for them, it is a subject full of constraint and generates fear, feelings expressed in the central nucleus of the study representation.

The consequences of this representation can reflect in the low search for health professionals to advise them about sexual activity ${ }^{(19)}$ and in the low adherence to gynecological consultations. Between the adolescents without sexual activity, the search for this service is null(20). The reasons why adolescents go to a gynecological clinic are suspect of pregnancy, PAP smear test ${ }^{(21)}$ and gynecological problems ${ }^{(22)}$, demonstrating that the focus of sexual health promotion is almost inexistent ${ }^{(23)}$. Besides that, only $44.6 \%$ of adolescents with an active sexual life see a gynecologist every two years ${ }^{(20)}$.

Although it is not apparent within the results of the present study, it is known that sexual initiation is happening earlier in this age group and as the age advances, the number of partners is higher, a phenomenon more observed within men ${ }^{(24)}$. A study with Portuguese adolescents showed that those who had their first sexual intercourse at 13 years old were the fewer to used condoms ${ }^{(19)}$. Therefore, considering the gynecological consultation as a great opportunity to guide adolescents, it is the professionals' responsibility to talk about those issues and particularities, helping them to live their sexuality with freedom, responsibility and informed about the health risks.

The peripheral elements constitute an interconnection between the central nucleus and the reality where the representations are formed and where they work ${ }^{(13)}$. Thus, the term embarrassment, present in the first periphery reinforces the socio-cultural norms, present in the $\mathrm{CN}$. We believe the adolescents associate embarrassment to the belief that the gynecological consultation should be revealing of sexual practices, which cannot be or should not be revealed to the parents. Embarrassment it is also associated to the belief of having to take the clothes off in front of a stranger to do the gynecological exam. A study with pregnant adolescents showed that $68 \%$ were embarrassed or constrained when the gynecologist was a man ${ }^{(22)}$. Besides that, many did not look for the service because of fear or by not being informed of the need to prevent their reproductive health ${ }^{(22)}$.

It is important to note that not all gynecological consultation require a gynecological exam ${ }^{(25)}$. The consultation can be centered in sexual and reproductive health
The representations of adolescents about gynecological consultation Gomes VLO, Fonseca AD, Oliveira DC, Silva $C D$, Acosta DF, Pereira FW 
promotion for the adolescent or couple. It is possible to establish attentive listening, clarification of doubts, an honest and clear conversation. For it to happen, the environment should be welcoming and the professional should create trust and confidentiality as well as to be respectful and comprehensive ${ }^{(25)}$.

It is in the peripheral where new information and facts are, capable to put in question the central nucleus. With that, the peripheral elements act as norms and other social determinants in the $\mathrm{CN}^{(14)}$, resulting in mobility and flexibility that characterizes the social representations. In the periphery of this study, there is the word prevention, possibly referred to STDs and pregnancy, themes addressed in sexual and reproductive education programs developed for adolescents in schools and health units ${ }^{(18,26)}$. In the second periphery, along with the negative aspects, as pregnancy, pain and boring, the gynecological consultation was associated to positive terms, as learning about sex and clarifying doubts. However, these positive contents are not incorporated to the social representation of the gynecological consultation, requiring more investment on them, making the representation become positive.

So it is possible to infer that adolescents perceive the possibility to incorporate the gynecological consultation to their everyday, to clarify doubts, to learn about sex and to adopt preventive measures. This consultation can represent a space for orientation of their rights to obtain free contraception pills, condoms and, as an exception resource, the emergency contraception ${ }^{(27)}$. It is important to highlight that from the ethical and legal stand point there is support in reproductive age, that is, from 10 years old $^{(28)}$, to obtain information and resources to protect themselves from aggravations, as well as to guarantee the secrecy and confidentiality of the consultation.

Therefore, it is equivocated to require the presence of a responsible to attend the adolescents under 16 years old, as it is explicit in this study. Adolescents have the right to be seen alone and the information obtained during the consultation kept in secrecy, except if it causes harm to their own health or others ${ }^{(25)}$. Factors as the lack of information, in a certain way, can influence the representation of adolescents regarding the role of the gynecological consultation in the sexual and reproductive health. Adding to that, a study shows the dissatisfaction of adolescents during the consultation associated to the lack of attention from the professional, the waiting time and the lack of dialogue ${ }^{(11)}$. Those findings can be configured as obstacles to search orientation and to adhere to the consultation.

Thus, to modify those representations, strategies should be associated, individual or collective, with opportunity to discuss doubts and problems of situations ${ }^{(21)}$. It is also needed to promote good relationships between adolescents and professionals, surpassing the established therapeutic limits, aiming to proportionate knowledge for a safe and healthy sexual and reproductive behavior.

\section{CONCLUSION}

Although this study scenario contemplates private and public schools, located in the city center and out bounds, we cite as a limitation the reduced number of institutions, as well as the focus in students from the last year of middle school.

However, the objective was accomplished, because we learned that the $\mathrm{CN}$ of this representation is formed by the terms fear and constraint. The peripheral elements reinforce the representation of the consultation as something boring, causing embarrassment and pain. Those representations can justify the absence of adolescents in the clinics for sexual health promotion. It is also important to observe that considering the group size, it was not evoked many words, which can indicate lack of information or little importance regarding the gynecological consultation. On the other hand, some terms, of recent incorporation, seem to bring a new conception of gynecological consultation, pointing it as a possibility for prevention, to learn about sex and to clarify doubts.

In the central nucleus still counts the term sex referring to sexual act. It associates the belief that for adolescents, the gynecological consultation has indication only after sexual initiation which they do not want to reveal to the mothers, as explicit in the groups. As aggravating, they do not know their rights and they believe in the impossibility to be seen alone.

So, an excellent space is lost, where individual, safe and free of prejudice orientations are given, ensuring the access to more adequate contraception methods to adolescents. In it, more polemic topics could be talked through, as the negotiation to use condom, the risks of abortion and the sexual violence.

Some evoked terms indicate that besides their fears, they see the possibility to take advantage of gynecological consultations as an action of health education. It is important to highlight that this is a great opportunity for the professionals, especially nurses, to act with the adolescents, forming support networks with the parents and the school. In this context, it is important to establish a trust relationship that facilitate dialog with the adolescent, clarifying the guarantee of their right to privacy and the trust during the consultation. It is also important to incentive the adolescent role and, consequently, the responsibility for their choices.

Another path to make the gynecological consultation attractive to youngers is to involve it in their daily reality. For that, campaigns aiming to capacitation and reflection about the gynecological consultation can be delivered through the internet and social networks, which are part of communication channels broadly explored by the adolescents. 


\section{REFERENCES}

1. Brêtas JRS, Moreno RS, Eugênio DS, Sala DCP, Vieira TF, Bruno PR. Os rituais de passagem segundo adolescentes. Acta Paul Enferm. 2008;21(3):404-11.

2. Brêtas JRS, Tadini AC, Freitas MJD, Goellner MB. Significado da menarca segundo adolescentes. Acta Paul Enferm. 2012;25(2):249-55.

3. Heilborn ML. Por uma agenda positiva dos direitos sexuais da adolescência. Psic Clin (Rio de Janeiro) [Internet]. 2012 [citado 2013 jul. 2];24(1):57-68. Disponível em: www.scielo. $\mathrm{br} / \mathrm{pdf} / \mathrm{pc} / \mathrm{v} 24 \mathrm{n} 1 / 05 . \mathrm{pdf}$

4. Decat $P$, Nelson $E$, Meyer $S$, Jaruseviciene $L$, Orozco $M$, Segura $Z$, et al. Community embedded reproductive health interventions for adolescents in Latin America: development and evaluation of a complex multi-centre intervention. BMC Public Health [Internet]. 2013 [cited 2013 July 13];13:31. Available from: http://www.biomedcentral.com/1471-2458/13/31

5. Shashikumar R, Das RC, Prabhu HR, Srivastava K, Bhat PS, Prakash J, et al. A cross-sectional study of factors associated with adolescent sexual activity. Indian J Psychiatry [Internet] 2012 [cited 2013 July 13];54(2):138-43. Available from: http:// www.indianjpsychiatry.org/text.asp?2012/54/2/138/99532

6. Dietrich J, Khunwane M, Laher F, Bruyn G, Sikkema KJ, Gray G. "Group sex" parties and other risk patterns: a qualitative study about the perceptions of sexual behaviours and attitudes of adolescents in Soweto, South Africa. Vulnerable Child Youth Stud [Internet]. 2011[cited 2013 July 16];6(3):244-54. Available from: http://www.ncbi.nlm.nih.gov/pmc/articles/ PMC3405849/

7. Anjos RHD, Silva JAS, Val LF, Rincon LA, Nichiata LY. Differences between female and male adolescents regarding individual vulnerability to HIV. Rev Esc Enferm USP [Internet]. 2012 [cited 2013 Aug 15];46(4):829-37. Available from: http://www. scielo.br/pdf/reeusp/v46n4/en_07.pdf

8. Boletim Epidemiológico Aids-DST. Ministério da Saúde [Internet]. Brasília; 2011 [citado 2013 dez. 13];7(1). Disponível em: http://bvsms.saude.gov.br/bvs/periodicos/boletim_epidemiologico_aids_dst_v7_n1.pdf

9. Bergamaschi SFF, Praça NS. The adolescent puerpera's experience of taking care of the newborn at home. Rev Esc Enferm USP. 2008;42(3):454-60.

10. Brasil. Presidência da República. Portal Brasil. Campanhas educativas previnem a gravidez precoce no País [Internet]. Brasília; 2012 [citado 2013 dez. 13]. Disponível em: http:// www.brasil.gov.br/saude/2012/04/campanhas-educativasprevinem-a-gravidez-precoce-no-pais
11. Pereira SM, Taquete SR, Perez MA. Consulta ginecológica sob a ótica de estudantes do ensino médio do Rio de Janeiro, RJ. Rev Saúde Pública [Internet]. 2013 [citado 2014 fev.5];47(1):2-10. Disponível em: http://www.scielo.br/pdf/ rsp/v47n1/02.pdf

12. Lima JD. O despertar da sexualidade na adolescência. In: Pereira JL, Fanelli CMT, Pereira RCR, organizadores. Sexualidade na adolescência no novo Milênio. Rio de Janeiro: Universidade Federal do Rio de Janeiro; 2007. p.15-25.

13. Sá CP. Núcleo central das representações sociais. 2a ed. Petrópolis: Vozes; 2002. Introdução; p.13-27.

14. Oliveira DC, Marques S, Gomes AMT. Análise das evocações livres: uma técnica de analise estrutural das representações sociais. In: Moreira ASP, Camargo BV, Jesuíno JC, Nóbrega SM, organizadores. Perspectivas teórico-metodológicas em representações sociais. João Pessoa: Ed. Universitária; 2005. p. 573-601.

15. Banchs MA. Representaciones sociales en proceso: su análisis a través de grupos focales. In: Moreira ASP, Camargo BV, Jesuíno JC, Nóbrega SM, organizadores. Perspectivas teórico-metodológicas em representações sociais. João Pessoa: Ed. Universitária; 2005. p. 401-23.

16. Gatti BA. Grupo focal na pesquisa em ciências sociais e humanas. Brasília: Líber; 2005.

17. Bardin L. Análise de conteúdo. Lisboa: Edições 70; 2011. A codificação; p.133-46.

18. Brasil. Ministério da Saúde; Secretaria de Vigilância em Saúde, Departamento de DST, AIDS e Hepatites Virais. Adolescentes e jovens para a educação entre pares: sexualidades e saúde reprodutiva. Brasília; 2011.

19. Ferreira MMSRS, Torgal MCLFPR. Life styles in adolescence: sexual behavior of Portuguese adolescents. Rev Esc Enferm USP [Internet]. 2011 [cited 2013 July 15];45(3):589-95. Available from: http://www.scielo.br/pdf/reeusp/v45n3/ en_v45n3a06.pdf

20. Miranda AE, Gadelha AMJ, Szwarcwald CL. Padrão de comportamento relacionado às práticas sexuais e ao uso de drogas de adolescentes do sexo feminino residentes em Vitória, Espírito Santo, Brasil, 2002. Cad Saúde Pública [Internet]. 2005 [citado 2013 jul. 25];21(1):207-16. Disponível em: http://www.scielo.br/pdf/csp/v21n1/23.pdf

21. Gomes VLO, Amarijo CL, Cazeiro CC, Costa JES. Conhecimento acerca da consulta ginecológica para adolescentes, produzido no campo da medicina. Adolesc Saúde [Internet]. 2011 [citado 2013 ago. 2];8(4):48-54. Disponível em: file:///C:/ Documents\%20and\%20Settings/2509501/Meus\%20documentos/Downloads/v8n4a07.pdf
The representations of adolescents about gynecological consultation Gomes VLO, Fonseca $A D$, Oliveira DC, Silva $C D$, Acosta DF, Pereira FW 
22. Carvacho IE, Mello MB, Morais SS, Silva JLP. Fatores associados ao acesso anterior à gestação a serviços de saúde por adolescentes gestantes. Rev Saúde Pública. 2008; 42(5):886-94.

23. Grego MC, Ohara CVS, Pereira SR, Brêtas JRS. Oficina de autoexame de mamas: uma estratégia para o autoconhecimento de adolescentes. Acta Paul Enferm. 2011; 24(4):493-9.

24. Panatto D, Amicizia D, Trucchi C, Casabona F, Lai PL, Bonanni $P$, et al. Sexual behaviour and risk factors for the acquisition of human papillomavirus infections in young people in Italy: suggestions for future vaccination policies. BMC Public Health [Internet]. 2012 [cited 2013 Aug 7];12:623. Available from: http://www.ncbi.nlm.nih.gov/pmc/articles/ PMC3490840/\#_ffn_sectitle

25. Brasil. Ministério da Saúde. Caderneta de Saúde do Adolescente. Brasília; 2009.
26. Brêtas JRS, Ohara CVS, Jardim DP, Muroya RL. Conhecimentos de adolescentes sobre Doenças Sexualmente Transmissíveis: subsídios para prevenção. Acta Paul Enferm. 2009;22(6):786-92.

27. Silva CR. Responsabilidades no exercício da sexualidade do adolescente. In: Pereira JL, Fanelli CMT, Pereira RCR, organizadores. Sexualidade na adolescência no novo milênio. Rio de Janeiro: Universidade Federal do Rio de Janeiro, 2007. p. 26-31.

28. Brasil. Ministério da Saúde; Secretaria de Atenção à Saúde, Departamento de Ações Programáticas Estratégicas. Marco teórico e referencial: saúde sexual e saúde reprodutiva de adolescentes e jovens [Internet]. Brasília; 2006 [citado 2013 ago. 7]. Disponível em: http://dtr2001.saude.gov.br/editora/produtos/livros/pdf/06_0611_M.pdf. 